\title{
Potensi Pakan Ruminansia dengan Penampilan Produksi Gas Secara In Vitro
}

\section{Potential of Ruminant Feed with Appearance of In Vitro Gas Production}

\author{
Firsoni ${ }^{*}$ dan E. Lisanti ${ }^{2}$ \\ ${ }^{1}$ Badan Tenaga Nuklir Nasional, Jakarta \\ ${ }^{2}$ Fakultas Matematika dan Ilmu Pengetahuan Alam, Universitas Negeri Jakarta \\ *E-mail: firsoni@yahoo.com \\ (Diterima: 8 Agustus 2017; Disetujui: 15 September 2017)
}

\begin{abstract}
ABSTRAK
Indonesia mempunyai berbagai jenis bahan pakan dengan kualitas berbeda yang bisa dimanfaatkan sebagai pakan ruminansia. Salah satu cara untuk mengevaluasinya adalah dengan melihat penampilan produksi gas bahan pakan tersebut secara in-vitro. Bahan pakan yang diujikan pada penelitian ini adalah tepung kulit kopi, kulit kacang tanah, rumput lapang, daun turi, jerami padi dan jerami padi fermentasi. Sampel ditimbang $200 \pm 5 \mathrm{mg}$, dimasukkan ke dalam syringe glass $100 \mathrm{ml}$, ditambahkan media cairan rumen kerbau yang sudah dicampurkan larutan bicarbonat buffer sebanyak $30 \mathrm{ml}$, selanjutnya diinkubasi di dalam waterbath pada $39^{\circ} \mathrm{C}$ selama 48 jam. Software Neway dipakai untuk menghitung nilai fitted gas dan rancangan acak kelompok dengan 4 blok untuk menganalisa keragaman. Variabel yang diukur adalah produksi gas 2, 4, 6, 8, 10, 12, 24, 48, 72 dan 96 jam, degradasi bahan organik, potensi produksi (a+b), laju produksi gas (k), amonia $\left(\mathrm{NH}_{3}\right)$ dan asam lemak terbang (VFA Total). Hasil produksi gas tertinggi setelah 24, 48 dan 72 jam dari perlakuan rumput lapang (C) yaitu 36,33; 51,12 dan 56,29 ml/200 mg BK tapi setelah 96 jam dari jerami padi yaitu 59,60 ml/200 mg BK, sedangkan terendah (24, 48, 72 dan 96 jam) kulit kopi yaitu 6,08; 7,77; 7,61 dan 7,68 ml/200 mg BK. Potensi produksi gas tertinggi dihasilkan jerami padi yaitu $69,13 \mathrm{ml} / 200 \mathrm{mg}$ BK dan terendah kulit kopi yaitu 7,72 ml/200 mg BK. Persentase produksi gas setelah 24 jam tertinggi dihasilkan daun turi (D) yaitu 91,46\% dan terendah jerami padi (E) yaitu 41,22\%. Jerami padi potensial diolah lagi untuk mengurangi serat kasarnya, sehingga bisa dijadikan pakan ternak mendekati rumput lapang, sementara itu kulit kopi dan kulit kacang tanah perlu dilakukan kajian lebih lanjut, karena potensi produksi gasnya rendah yaitu 7,72 dan $11,45 \mathrm{ml} / 200 \mathrm{mg} \mathrm{BK}$.
\end{abstract}

Kata kunci: produksi gas, degradabilitas bahan organik, jerami padi, fermentasi, kualitas pakan

\section{ABSTRACT}

Indonesia has many kinds of feed stuff with different qualities that can be used as ruminants feed. One way to evaluate it is analyzing the performance of the feed gas production value in vitro. Feed ingredients tested in this study were the flour of coffee hull, peanut hull, field grass, turi leaves, rice straw and fermented rice straw. Samples weighed $200 \pm 5 \mathrm{mg}$, put into a $100 \mathrm{ml}$ syringe glass, added $30 \mathrm{ml}$ buffalo rumen liquor with bicarbonate buffer medium, then incubated in the water bath at $39{ }^{\circ} \mathrm{C}$ for 48 hours. Neway software and random block design with 4 blocks are used to calculate the value of fitted gas and to analyze the variance. The variables measured were gas production 2, 4, 6, 8, 10, 12, 24, 48, 72 and 96 hours, organic material degradable, gas production potential $(a+b)$, gas production rate $(k)$. The highest gas production 24, 48 and 72 hours from the field grass treatment (C) was 36,33; 51,12 and 56,29 ml/200 $\mathrm{mg}$ DM but 96 hours of rice straw ie 59,60 ml/200 mg DM, while the lowest (24, 48, 72 and 96 hours) of coffee skin (6,08; 7,77; 7,61 and 7,68 ml/200 mg DM respectively). The highest gas production potential of rice straw is $69,13 \mathrm{ml} / 200 \mathrm{mg} \mathrm{DM}$ and the lowest of coffee skin is 7,72 $\mathrm{ml} / 200 \mathrm{mg} \mathrm{BK}$. The highest percentage of gas production after 24 hours was obtained turi leaves (D): 91,46\% and the lowest rice straw (E): 41,22\%. Rice straw can be suggested to be field grass substitution by processed again to reduce its crude fiber content, while the coffee and peanut hulls need further study, due to low gas production potential of 7,72 and $11,45 \mathrm{ml} / 200 \mathrm{mg}$ DM.

Keywords: gas production, organic matter degradability, rice straw, fermentation, feed quality 


\section{PENDAHULUAN}

Kopi dan kacang tanah merupakan salah satu sumber divisa negara Indonesia dari perkebunan. Produksi kopi nasional sekitar 638.522 ton tahun 2016 (Triyanti, 2016) dan produksi kacang tanah nasional sekitar 657.590 ton tahun 2015 (Sholihah, 2015). Kulit kopi dan kulit kacang tanah merupakan hasil samping yang juga potensial dijadikan pakan ruminansia. Produksi padi nasional tahun 2015 sebanyak 75,36 juta ton gabah kering giling (GKG) (BPS, 2016). Jerami padi merupakan sumber pakan yang jauh lebih banyak yaitu mencapai 65.000.000 ton bahan kering per tahun secara nasional (Firsoni dan Harahap, 2015). Pemanfaatan bahan pakan ini secara luas dapat mengurangi biaya pakan dan meningkatkan populasi yang bisa dipelihara dengan memanfaatkan sumber daya pakan yang ada.

Kulit kopi, kulit kacang tanah, daun turi dan jerami padi termasuk beberapa jenis bahan pakan yang jarang dimanfaatkan petani, sementara rumput lapang sudah biasa digunakan sebagai pakan. Kulit buah kopi (coffee husk) dan kacang (peanut husk) diperoleh setelah dipisahkan dari kulit nya pada saat pengolahan, sedangkan jerami padi merupakan hasil ikutan panen padi. Kulit kopi mengandung protein kasar sekitar 6,6\% (Pamungkas dan Utomo, 2008), kulit kacang tanah mengandung protein kasar 8.4\% (Murni et al., 2008), jerami padi mengandung protein kasar 4.55\% (Simanihuruk dan Sirait, 2010), 5.56\% ( Sudarwati dan Susilawati, 2013), 4.5 - 5.85 (Andini, 2013), jerami padi fermentasi mengandung protein kasar 6.23-6.56\% (Sudarwati dan Susilawati, 2013) dan rumput lapang mengandung protein kasar 8.78\% (Simanihuruk dan Sirait, 2010).

Ternak ruminansia merupakan hewan yang sangat mudah beradaptasi dengan berbagai jenis pakan yang tersedia, karena mempunyai perut sejati yaitu rumen yang bisa memfermentasi semua jenis bahan pakan memanfaatkan mikroba yang terdapat di dalamnya. Peran mikroba pada ternak ruminansia sangat penting, karena $65 \%$ pakan utama ruminansia adalah mikroba. Secara umum kebutuhan pakan ruminansia adalah pakan dasar atau pakan utama, pakan konsentrat sebagai penguat. Produktivitas ternak ditentukan oleh kualitas dan kuantitas pakan yang dikonsumsi dan kandungan zatzat anti nutrisi seperti tannin, lignin (Haryanto, 2012), saponin (Nista, 2010) dan tagitinin (Firsoni, 2014).

Teknik in-vitro produksi gas merupakan salah satu metoda untuk melakukan evaluasi kualitas pakan terutama untuk ruminansia. Produksi gas selama inkubasi merupakan produk buangan dari fermentasi substrat didalam tabung seperti gas $\mathrm{CH}_{4}, \mathrm{CO}_{2}, \mathrm{O}_{2}, \mathrm{H}_{2} \mathrm{~S}$ dan gas lainnya. Produksi gas menggambarkan tingkat proses fermentasi yang terjadi, sehingga diperoleh informasi mengenai laju produksi gas sesuai dengan sifat kimia bahan pakan yang diujikan. Informasi ini juga erat kaitannya dengan proses fermentasi dan degradasi substrat didalam tabung fermentor selama inkubasi. Analisa dengan teknik produksi gas merupakan salah satu cara untuk evaluasi kualitas pakan yang cukup murah dan bermanfaat (Kurniawati, 2007).

Perbedaan sifat kimia pakan akan memberikan nilai produksi gas yang berbeda. Pakan sumber karbohidrat akan menghasilkan produksi yang relatif lebih tinggi dibandingkan dengan pakan sumber protein. Disini bisa diprediksi keberadaan zat anti nutrisi yang selalu akan menghasilkan produksi gas yang rendah, karena aktifitas mikroba tertentu terhambat. Untuk itu dilakukan penelitian melihat potensi pakan dari data produksi gas yang dihasilkan.

\section{METODE}

\section{Bahan Penelitian}

Bahan pakan yang diujikan di dalam penelitian ini yaitu kulit kopi, kulit kacang tanah, daun turi kering yang diperoleh dari propinsi Nusa Tenggara Barat digiling halus lagi dengan grinder kecil. Rumput lapang, 
jerami padi dan jerami padi fermentasi dikeringkan di oven $55-60{ }^{\circ} \mathrm{C}$ selama 3 - 4 hari, setelah kering digerus halus dengan grinder kecil dicampur homogen sesuai dengan formula perlakuan. Media inkubasi adalah cairan rumen kerbau yang difistula, larutan buffer bicarbonat $\left(\mathrm{HCO}_{3}\right.$ buffer, makromineral, mikromineral, rezasurin) dan larutan pereduksi.

Bahan kimia yang digunakan dalam penelitian ini yaitu larutan neutral detergent solution (NDS) yang terdiri atas sodium lauryl sulfat, EDTA (T3), $\mathrm{Na}_{2} \mathrm{HPO}_{4}$, dan ethoxy ethanol; larutan digestion mixture terdiri atas $\mathrm{CuSO}_{4}$ dan $\mathrm{K}_{2} \mathrm{SO}_{4}$ dalam $\mathrm{H}_{2} \mathrm{SO}_{4}$ pekat; larutan makromineral terdiri atas $\mathrm{Na}_{2} \mathrm{HPO}_{4}$, $\mathrm{KH}_{2} \mathrm{PO}_{4}, \mathrm{MgSO}_{4} .7 \mathrm{H}_{2} \mathrm{O}$, dan aquadest; larutan mikromineral terdiri atas $\mathrm{CaCl}_{2} \cdot 2 \mathrm{H}_{2} \mathrm{O}$, $\mathrm{MnCl}_{2} \cdot 4 \mathrm{H}_{2} \mathrm{O}, \quad \mathrm{CoCl}_{2} \cdot 6 \mathrm{H}_{2} \mathrm{O}, \quad \mathrm{FeCl}_{3} \cdot 6 \mathrm{H}_{2} \mathrm{O}$, dan aquadest; larutan buffer terdiri atas $\mathrm{NaHCO}_{3}, \mathrm{NH}_{4} \mathrm{HCO}_{3}$, dan aquadest; larutan pereduksi terdiri atas $\mathrm{NaOH} 1 \mathrm{M}, \mathrm{Na}_{2} \mathrm{~S} .9 \mathrm{H}_{2} \mathrm{O}$, dan aquadest; Indikator Conway terdiri atas brom kresol green, metil red, etanol absolute, $\mathrm{H}_{3} \mathrm{BO}_{3}$, dan aquadest; larutan $\mathrm{NaOH} 0,1 \mathrm{~N}$, $\mathrm{HCl} 0,1 \mathrm{~N}, \mathrm{HCl} 0,01 \mathrm{~N}$, dan $\mathrm{NaOH} 50 \%$, larutan $\mathrm{H}_{2} \mathrm{SO}_{4} 15 \%$, resazurin $0,1 \%, \mathrm{~K}_{2} \mathrm{CO}_{3}$ jenuh, Phenolptalin $0,1 \%, \mathrm{NaCl} 20 \%$, aseton, vaselin, dan sampel pakan.

Proses pembuatan jerami padi fermentasi dilakukan dengan cara menambahkan starter Mikrostar LA2 yang bisa mendegradasi serat kasar. Beberapa bahan yang digunakan untuk pembuatan jerami padi fermentasi yaitu starter Mikrostar LA2, dedak, urea, dan molases dengan perbandingan (10 : $0.075: 0.05: 0.015: 0.04)$ serta ditambahkan air secukupnya (Andini, 2013)

\section{Peralatan yang digunakan}

Alat-alat yang digunakan dalam penelitian ini terdiri atas oven $55^{\circ} \mathrm{C}$, oven $105^{\circ} \mathrm{C}$, tanur $590^{\circ} \mathrm{C}$ merk Pyrolabo, labu kjedahl (destruksi dan destilasi), pemanas, buret $50 \mathrm{ml}$, pipet gondok $1 \mathrm{ml}$, buret $10 \mathrm{ml}$, labu erlenmeyer $100 \mathrm{ml}$ dan $2000 \mathrm{ml}$, syringe glass $100 \mathrm{ml}$, waterbath, cawan porselen, cawan Conway, mikropipet $1 \mathrm{ml}$ dan $5 \mathrm{ml}$, sentrifus merk Hitachi, tabung sentrifus, timbangan digital merk Santorius, grinder, termos, blender, dispenser, thermostat, parafilm, kain kassa, dan 1 set alat destilasi merk Glascoel.

\section{Prosedur In-vitro Produksi Gas}

Cairan rumen kerbau diambil segar melalui cannulae, diblender dan disaring dengan kain kasa yang bersih, lalu dicampurkan dengan media buffer bicarbonat (Khrisnamoorthy, 2001). Sampel ditimbang $200 \pm 5 \mathrm{mg}$ dan dimasukkan ke dalam syringe glass ukuran $100 \mathrm{ml}$, kemudian ditambahkan $30 \mathrm{ml}$ cairan rumen yang sudah ditambahkan larutan buffer bicarbonat dan diinkubasi di dalam waterbath $39^{\circ} \mathrm{C}$. Parameter yang dihitung adalah produksi gas selama inkubasi $0,2,4,6,8,24$ dan 48 jam, degradabilitas bahan organik, amonia dan VFA total setelah 48 jam inkubasi.

Pengukuran amonia $\left(\mathrm{NH}_{3}\right)$ menggunakan metode mikrodifusi Conway (Conway, 1950), pengukuran VFA total berdasar metode AOAC (2010). Bahan organik yang didegradasi (DBO) diperoleh berdasarkan persamaan hasil eksperimen Menke et al. (1979) di dalam (Aghsaghali et al., 2017) dimana DBO (\%) $=4.88+0.889$ $\mathrm{GP}+0.45 \mathrm{CP}+0.0651$ Ash (GP: produksi gas selama 24 jam, CP: protein kasar, Ash: abu).

\section{Statistik}

Rancangan percobaan yang digunakan adalah Rancangan Acak Kelompok (RAK) dengan enam perlakuan dan empat kali pengulangan sebagai kelompok. Perlakuan yang diuji yaitu $\mathrm{A}=$ kulit biji kopi; $\mathrm{B}=$ kulit kacang tanah; $\mathrm{C}=$ rumput lapang; $\mathrm{D}=$ daun turi; $\mathrm{E}=$ jerami padi dan $\mathrm{F}=$ jerami padi fermentasi. Jika terdapat perbedaan signifikan pada analysis of variance (ANOVA), maka dilakukan uji lanjutan Least Significant Different (LSD) untuk melihat perbedaan di antara perlakuan tersebut. 
Tabel 1. Nilai rataan produksi gas selama 48 jam inkubasi secara in vitro.

\begin{tabular}{ccccccc}
\hline \multirow{2}{*}{ Perlakuan } & \multicolumn{7}{c}{ Lama Inkubasi (Jam) } \\
\cline { 2 - 7 } & 2 & 4 & 6 & 8 & 24 & 48 \\
\hline A & $3.11^{\mathrm{a}}$ & $3.39^{\mathrm{a}}$ & $3.25^{\mathrm{a}}$ & $4.24^{\mathrm{a}}$ & $6.08^{\mathrm{a}}$ & $7.77^{\mathrm{a}}$ \\
B & $3.12^{\mathrm{a}}$ & $4.08^{\mathrm{a}}$ & $5.03^{\mathrm{ab}}$ & $5.84^{\mathrm{a}}$ & $9.78^{\mathrm{b}}$ & $11.55^{\mathrm{b}}$ \\
C & $7.13^{\mathrm{bc}}$ & $11.31^{\mathrm{c}}$ & $14.67^{\mathrm{d}}$ & $18.3^{\mathrm{c}}$ & $36.33^{\mathrm{f}}$ & $51.12^{\mathrm{f}}$ \\
D & $8.18^{\mathrm{c}}$ & $13.46^{\mathrm{d}}$ & $19.01^{\mathrm{d}}$ & $24.28^{\mathrm{d}}$ & $34.27^{\mathrm{e}}$ & $38.01^{\mathrm{c}}$ \\
E & $3.09^{\mathrm{a}}$ & $5.09^{\mathrm{ab}}$ & $6.72^{\mathrm{bc}}$ & $8.85^{\mathrm{b}}$ & $28.35^{\mathrm{d}}$ & $43.21^{\mathrm{e}}$ \\
F & $3.97^{\mathrm{ab}}$ & $6.72^{\mathrm{b}}$ & $8.35^{\mathrm{c}}$ & $10.11^{\mathrm{b}}$ & $25.48^{\mathrm{c}}$ & $38.85^{\mathrm{d}}$ \\
\hline
\end{tabular}

Keterangan: Huruf Superskrip yang berbeda pada kolom yang sama menunjukkan pengaruh yang berbeda nyata $(\mathrm{P}<0.05)$. (A: Kulit biji kopi, B: Kulit kacang tanah, C: Rumput lapang, D: Daun turi, E: Jerami padi, dan F: Jerami padi fermentasi).

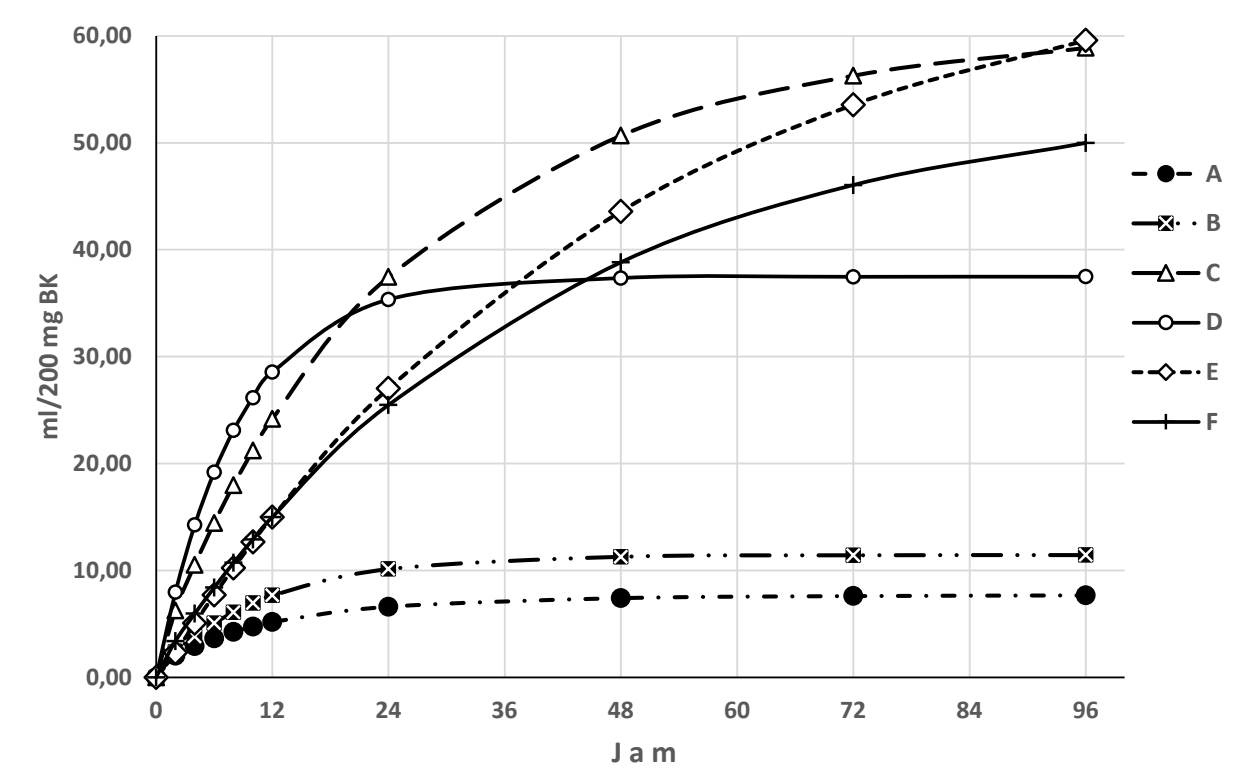

Gambar 1. Grafik laju produksi gas selama 96 jam (fitted value), hasil perhitungan software Neway (A: Kulit biji kopi, B: Kulit coklat, C: Rumput lapang, D: Daun turi, E: Jerami padi, dan F: Jerami padi fermentasi).

\section{HASIL DAN PEMBAHASAN}

\section{Produksi Gas}

Produksi gas yang dihasilkan berbeda nyata $(\mathrm{P}<0.01)$ diantara bahan pakan yang diujikan (Tabel 1). Hal ini menunjukkan karakteristik dan kandungan bahan kimia di dalamnya. Produksi gas tertinggi pada 2, 4, 6 dan 8 jam inkubasi dihasilkan oleh perlakuan daun turi secara berturut-turut yaitu $8.18,13.46,19.01$, dan $24.28 \mathrm{ml} / 200$ mg BK. Produksi gas tertinggi setelah 24 dan 48 jam inkubasi in-vitro dihasilkan oleh rumput lapang (perlakuan C) yaitu 36.33 dan $51.12 \mathrm{ml} / 200 \mathrm{mg} \mathrm{BK}$, sedangkan produksi gas terendah dihasilkan kulit biji kopi yaitu 6.08 dan $7.77 \mathrm{ml} / 200 \mathrm{mg}$ BK. Produksi gas terendah pada $2,4,6,8,10,12,24$ dan 48 jam dihasilkan kulit biji kopi yaitu 3.11, 3.39, 3.25, 4.24, 6.08 dan $7.77 \mathrm{ml} / 200$ mg BK. Pakan sumber energi, akhirnya menghasilkan produksi gas yang lebih tinggi dibandingkan pakan sumber protein. Produksi gas merupakan gambaran dari bahan organik yang difermentasi dengan baik di rumen (Pellikaana et al., 2011). Local feed 
Tabel 2. Kandungan Bahan Kering, Bahan Organik, dan Protein Kasar perlakuan.

\begin{tabular}{lccc}
\hline Nama Bahan & BK (\%) & BO (\%) & PK (\%) \\
\hline Kulit kopi & 87.1 & 92.8 & 6.83 \\
Kulit kacang tanah & 90.5 & 93.7 & 5.81 \\
Rumput lapang & 91.5 & 90.8 & 8.91 \\
Daun turi & 89.3 & 88.8 & 21.28 \\
Jerami padi & 92.1 & 80.1 & 4.79 \\
Jerami padi fermentasi & 92.8 & 76.6 & 7.03 \\
\hline
\end{tabular}

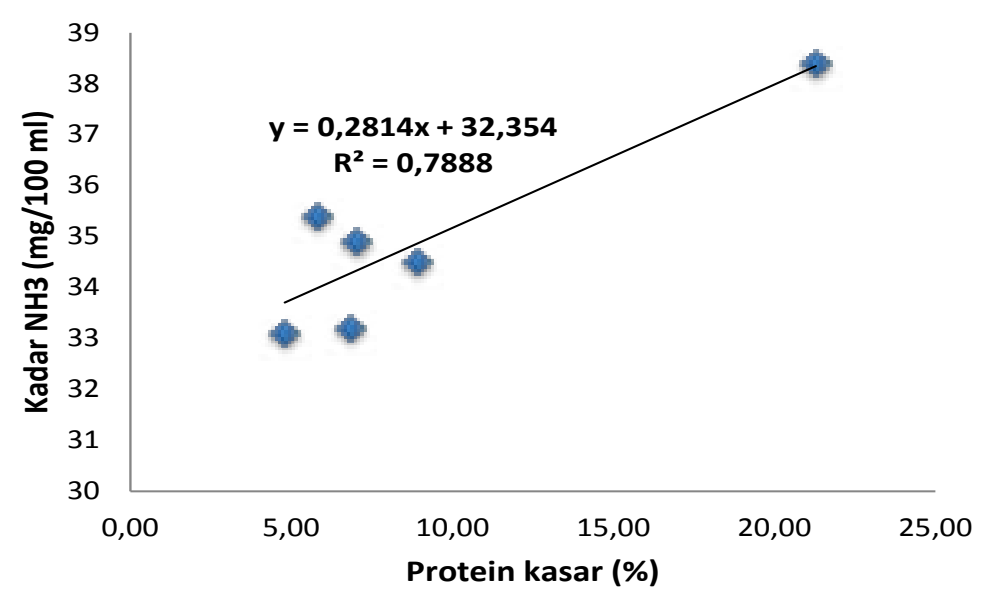

Gambar 2. Grafik korelasi antara kandungan Protein Kasar dengan kadar $\mathrm{NH}_{3}$ cairan rumen.

resources sangat penting karena ketersediaan dan manfaatnya sebagai pakan ternak sebagai sumber energi dan protein sebagai penyusun konsentrat, sehingga dapat memperkaya hasil fermentasi rumen (Wanapat et al., 2013).

Beberapa hal yang menyebabkan produksi gas rendah adalah peran zat anti nutrisi yang terdapat di dalam tanaman (Jayanegara, 2008; Hariadi dan Santoso, 2010; Firsoni, 2014). Kulit kopi mengandung $8,67 \%$ lignin dan $41,26 \%$ selulosa (Edahwati et al., 2014), kulit kacang tanah mengandung 63.5\% serat kasar dan 29,9\% lignin (Murni et al., 2008), jerami padi mengandung $4.55 \%$ protein kasar, $35.91 \%$ sellulosa dan 6.13\% lignin (Antonius, 2009). Daun turi mengandung saponin (Nista et al., 2010) dan tanin (Makalalag et al., 2015). Kandungan saponin daun turi sekitar $30 \mathrm{ppm}$ (Amananti et al., 2017). Hal ini terlihat pada kulit kopi dan kulit kacang tanah yang memberikan hasil produksi gas rendah, karena kandungan anti nutrisinya.

Gambar 1 menjelaskan laju produksi gas selama selama 96 jam dengan bantuan software "Neway" yang dikombinasikan Microsoft Excel, dimana perlakuan C, E dan $\mathrm{F}$ masih menunjukkan peningkatan produksi gas, sementara itu perlakuan A, B dan D telah menunjukkan grafik yang mendatar atau terjadi peningkatan produksi gas yang jauh lebih rendah. Hal ini disebabkan oleh masih banyak fraksi yang belum dicerna sampai 48 jam inkubasi pada rumput lapang, jerami padi dan jerami padi fermentasi, sedangkan pada kulit kopi, kulit kacang tanah dan daun turi sudah jauh berkurang. Salah satu cara peningkatan kualitas kulit kopi dan kulit kacang tanah adalah dengan fermentasi. Penambahan kulit buah kopi yang telah difermentasi sampai level $6 \%$ tidak mempengaruhi populasi mikrobia rumen (Badarina et al., 2014).

Selulosa adalah sumber organik terbarukan yang paling banyak melimpah di 


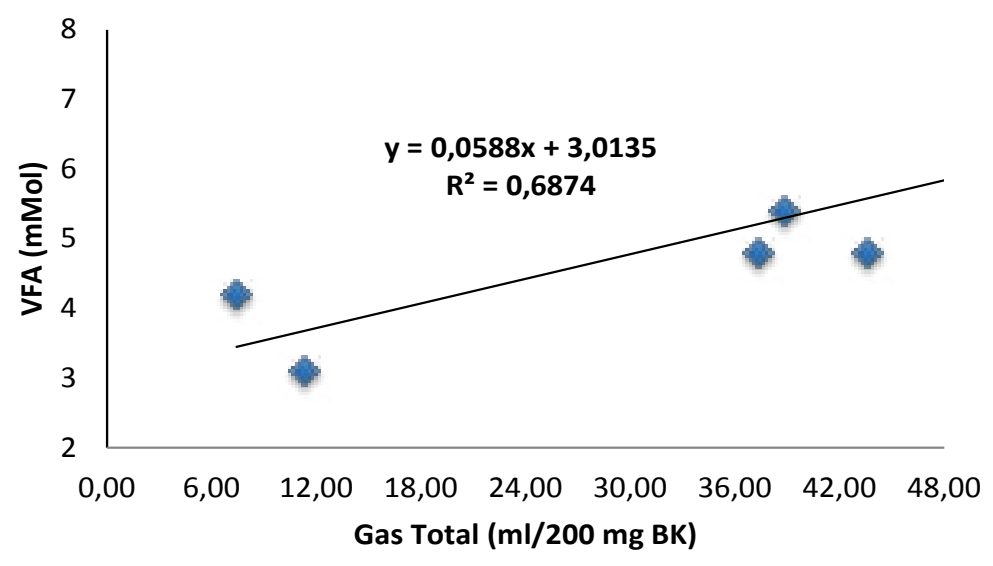

Gambar 3. Grafik korelasi antara Produksi Gas Total dengan kadar VFA Total cairan rumen.

Tabel 3. Data Produksi Gas 72 dan 96 jam; Data $(\mathrm{a}+\mathrm{b})$, c; Degradasi Bahan Organik, $\mathrm{NH}_{3}$ dan VFA total.

\begin{tabular}{lcccccc}
\hline & \multicolumn{7}{c}{ Perlakuan } \\
\cline { 2 - 7 } & A & B & C & D & E & F \\
\hline Produksi gas : & & & & & & \\
72 jam (ml/200 mg BK) & $7.61^{\mathrm{a}}$ & $11.43^{\mathrm{a}}$ & $56.29^{\mathrm{d}}$ & $37.47^{\mathrm{b}}$ & $53.56^{\mathrm{d}}$ & $46.06^{\mathrm{c}}$ \\
96 jam (ml/200 mg BK) & $7.68^{\mathrm{a}}$ & $11.45^{\mathrm{a}}$ & $58.89^{\mathrm{c}}$ & $37.48^{\mathrm{b}}$ & $59.60^{\mathrm{c}}$ & $49.99^{\mathrm{c}}$ \\
$(\mathrm{a}+\mathrm{b})(\mathrm{ml} / 200 \mathrm{mg} \mathrm{BK})$ & $7.72^{\mathrm{a}}$ & $11.45^{\mathrm{a}}$ & $61.47^{\mathrm{c}}$ & $37.48^{\mathrm{b}}$ & $69.13^{\mathrm{c}}$ & $54.77^{\mathrm{c}}$ \\
$\mathrm{K}$ & $0.09^{\mathrm{b}}$ & $0.09^{\mathrm{b}}$ & $0.04^{\mathrm{a}}$ & $0.12^{\mathrm{c}}$ & $0.02^{\mathrm{a}}$ & $0.03^{\mathrm{a}}$ \\
Rasio gas 24 jam/(a+b) (\%) & $78.41^{\mathrm{c}}$ & $85.44^{\mathrm{cd}}$ & $61.43^{\mathrm{b}}$ & $91.46^{\mathrm{d}}$ & $41.22^{\mathrm{a}}$ & $46.71^{\mathrm{a}}$ \\
Degradabilitas BO (\%) & $35.84 \mathrm{a}$ & $37.26 \mathrm{a}$ & $64.2 \mathrm{c}$ & $66.4 \mathrm{~d}$ & $61.43^{\mathrm{b}}$ & $65.16^{\mathrm{cd}}$ \\
NH $(\mathrm{mg} / 100 \mathrm{~mL})$ & $33.2^{\mathrm{a}}$ & $35.4^{\mathrm{a}}$ & $34.5^{\mathrm{a}}$ & $38.4^{\mathrm{b}}$ & $33.1^{\mathrm{a}}$ & $34.9^{\mathrm{a}}$ \\
VFA Total (mMol) & $4.2^{\mathrm{ab}}$ & $3.1^{\mathrm{a}}$ & $6.9^{\mathrm{c}}$ & $4.8^{\mathrm{b}}$ & $4.8^{\mathrm{b}}$ & $5.4^{\mathrm{b}}$ \\
\hline
\end{tabular}

Keterangan: Huruf Superskrip yang berbeda pada baris yang sama menunjukkan pengaruh yang berbeda nyata $(\mathrm{P}<0.05)$. (A: Kulit biji kopi, B: Kulit kacang tanah, C: Rumput lapang, D: Daun turi, E: Jerami padi, dan F: Jerami padi fermentasi). $(a+b=$ Potensi produksi gas 48 jam, $k=L a j u$ produksi gas)

Bumi dan tersebar luas di tanaman, bakteri, ganggang laut, dan biomassa lainnya yang lebih tinggi. Lignin adalah salah satu polimer organik yang paling melimpah pada tanaman, tepat di bawah selulosa (Chen, 2014). Lignoselulosa adalah komponen utama tanaman yang menggambarkan jumlah sumber bahan organik yang dapat diperbaharui. Unsur utama dari lignoselulosa adalah selulosa, hemiselulosa dan lignin (Anindyawati, 2010). Produksi gas yang rendah pada kulit kopi dan kulit kacang tanah adalah karena jumlah kandungan lignin dan sellulosa yang cukup tinggi, sehingga aktifitas mikroba jadi terbatas. Kulit kopi juga mengandung pektin sejumlah 6,52\% (Murni dan Suparjo, 2008).

Konsentrasi amonia cairan rumen perlakuan $\mathrm{C}$ (daun turi) berbeda nyata $(\mathrm{P}<0.05)$, dibandingkan dengan perlakuan lainnya yaitu $38.4 \mathrm{mg} / 10 \mathrm{ml}$ (Tabel 2). Pada Gambar 2 terlihat korelasi positif antara kandungan protein kasar dengan kandungan amonia cairan rumen setelah 48 jam inkubasi ( $\mathrm{R} 2=78,9 \%$ ). Konsentrasi ammonia dipengaruhi oleh kandungan protein kasar pakan (Getachew et al., 2004; Firsoni et al., 2011; Firsoni dan Yunita, 2014). 
Konsentrasi VFA total yang dihasilkan berkisar antara 3.1-6.9 mMol lebih rendah dari hasil pengujian Jayanegara dan Sofyan (2008) yaitu dari 3 jenis hijauan Salix alba, Rhus typhina dan Peltiphyllum peltatum dengan atau tanpa PEG (Polyethilenglycol) berkisar antara 8-22 mMol. Dimana tertinggi dihasilkan Pada Gambar 3 terlihat korelasi positif antara kandungan protein kasar dengan kandungan VFA total $(\mathrm{R} 2=68.7 \%)$, sesuai dengan pendapat Anantasok dan Wanapat (2012) bahwa penambahan konsentrat pada pakan dapat meningkatkan konsentrasi VFA.

Potensi produksi gas $(a+b)$ tertinggi pada perlakuan jerami padi yaitu 69.13 $\mathrm{ml} / 200 \mathrm{mg} \mathrm{BK}$, sementara rumput lapang juga mempunyai potensi produksi gas yang tinggi dan tidak berbeda nyata $(\mathrm{P}<0.05)$ yaitu 61,47 $\mathrm{ml} / 200 \mathrm{mg}$ BK (Tabel 3.). Produksi gas yang tertinggi dihasilkan pada 24 jam inkubasi adalah daun turi dimana $91.46 \%$ potensi gas telah dihasilkan dan paling lambat (rendah) adalah jerami padi yaitu baru $41.22 \%$ gas yang dihasilkan selama 24 jam inkubasi. Sementara itu potensi produksi gas terendah adalah kulit kopi dan kulit kacang tanah yaitu 7,72 dan $11,45 \mathrm{ml} / 200 \mathrm{mg}$ BK. Sebaliknya jerami padi mempunyai potensi produksi gas tertinggi yaitu $69.13 \mathrm{ml} / 200 \mathrm{mg} \mathrm{BK}$, tetapi pemanfaatannya kurang produktif karena kandungan serat kasar yang tinggi, karena baru $41.22 \%$ gas yang dihasilkan selama 24 jam inkubasi. Untuk meningkatkan kualitas pakan dilakukan fermentasi kulit kopi dengan memanfaatkan Phanerochaete chrysosporium (Nuraini et al., 2014) atau Pleurotus ostreatus (Badarina et al., 2015), fermentasi kulit kacang tanah dengan Aspergilus niger (Rosningsih, 2004) dan fermentasi jerami padi dengan menggunakan mikroba yang berasal dari isi rumen (Antonius, 2009; Andini, 2013).

\section{KESIMPULAN}

1. Rumput lapang (Perlakuan C) menghasilkan produksi gas tertinggi berbeda nyata $(\mathrm{P}<0.05)$ dengan perlakuan pakan lainnya.
2. Produksi gas tertinggi selama 24 dan 48 jam inkubasi dihasilkan rumput lapang, sedangkan 72 dan 96 jam dihasilkan oleh jerami padi.

3. Daun turi termasuk pakan sumber protein yang menghasilkan produksi gas yang tinggi dengan nilai potensi produksi gas $(\mathrm{a}+\mathrm{b})=61.47 \mathrm{ml} / 200 \mathrm{mg}$ dan tidak berbeda nyata $(\mathrm{P}>0.05)$ dengan jerami padi yaitu $69.13 \mathrm{ml} / 200 \mathrm{mg}$ BK dan rasio gas $24 /$ (a+b) tertinggi yaitu $91.46 \mathrm{ml} / 200 \mathrm{mg} \mathrm{BK}$.

4. Jerami padi masih punya potensi menjadi pakan yang baik, dengan menurunkan kandungan serat kasar dengan fermentasi atau cara lain.

\section{SARAN}

Pemanfaatan kulit kopi dan kacang tanah perlu dikaji lebih lanjut melihat potensi produksi gas nya yang rendah karena kandungan anti nutrisi di dalamnya.

\section{DAFTAR PUSTAKA}

Aghsaghali, A. M., N. Maheri-Sis, H. Mansouri, M. Razeghi, J. Shayegh and A. A. Golshani. 2011. Evaluating nutritional value of apple pomace for ruminants using in-vitro gas production technique, Annals of Biological Research, 2011, 2 (1) : 100-106.

Alwi, Y. 2009. Pemanfaatan Inokulum Feses Sapi Dalam Uji Kecernaan In Vitro ADF dan NDF Rumput Gajah (Pennisetum purpureum), Jurnal Ilmiah Ilmu-Ilmu Peternakan Mei, 2009, Vol. XII. No.2. 72-76.

Amananti, W., I. Tivani dan A. B. Riyanta. 2017. Uji Kandungan Saponin Pada Daun, Tangkai Daun dan Biji Tanaman Turi (Sesbania Grandiflora), Prosiding 2nd Seminar Nasional IPTEK Terapan (SENIT) 2017, Tegal. ISSN: 25799045; ISBN: 978-602-74355-1-3. p 209-212.

Anantasook, N. and M. Wanapat. 2012. 
Influence of Rain Tree Pod Meal Supplementation on Rice Straw Based Diets Using In vitro Gas Fermentation Technique, Asian-Aust. J. Anim. Sci. Vol. 25 , No. $3: 325-334$.

Andini, L. 2013. Teknologi Bioproses Fermentasi Jerami sebagai Pakan Ternak Ruminansia yang Ramah Lingkungan dengan MikroStar LA2. CV. Writing Revolution, Yogyakarta 55281. ISBN 978-602-7858-12-1 p 1923.

Anindyawati, T. 2010. Potensi Selulase Dalam Mendegradasi Lignoselulosa Limbah Pertanian Untuk Pupuk Organik, Berita Selulosa, Vol. 45, No. 2, Desember $2010: 70-77$.

Antonius. 2009. Utilization of fermented rice straw as substitution of elephant grass in cow feed. JITV 14(4): 270-277.

Badarina, I., D. Evvyernie, T. Toharmat dan E. N. Herliyana. 2014. Fermentabilitas Rumen dan Kecernaan In Vitro Ransum yang Disuplementasi Kulit Buah Kopi Produk Fermentasi Jamur Pleurotus ostreatus, Jurnal Sains Peternakan Indonesia Vol. 9, No. 2. 102-108.

BPS. 2016. Produksi Padi, Jagung, Dan Kedelai 2015, Berita Resmi Statistik, No. 62/07/ Th. XIX, 01 Juli 2016.

Budiarsana, I. G. M., I. K. Sutama dan T. Kostaman. 2006. Kajian Ekonomi Pemanfaatan Jerami Padi Fermentasi Sebagai Pakan Dasar Pada Ransum Kambing Peranakan Etawah Jantan Muda (The Economic Assessment of Utilization of Fermented Rice Straw as Basal Diets in the Ration of Etawah Grade Goat Ration). Seminar Nasional Teknologi Peternakan dan Veteriner 2006. p 575-579

Chen, H. 2014. Biotechnology of Lignocellulose: Theory and Practice., Chemical Industry Press, Beijing. p 2569.

Dyah, R. dan Triyanti. 2016. outlook Kopi Komoditas Pertanian Subsektor
Perkebunan. Pusat Data dan Sistem Informasi Pertanian Sekretariat Jenderal - Kementerian Pertanian $p$ 9-16.

Edahwati, L., D. S. Perwitasari dan N. D. Siswati. 2014. Penurunan Lignin Kulit Buah Kopi dengan Metode Organosolve. Eksergi, 11(02), p 7-10.

Firsoni dan R. Yunita. 2014. Uji Degradabilitas Pakan Komplit yang Mengandung Daun Chromolaena odorata secara In-Vitro. Jurnal Peternakan Indonesia, Juni 2014, ISSN 1907-1760. Vol. 16 (2). 89-93.

Firsoni dan S. Harahap. 2015. Kajian Pemanfaatan Jerami Padi Sebagai Pakan Ternak Sapi Di Indonesia., Prosiding Seminar Nasional II Pengembangan Ternak Lokal Unand, Padang., ISBN: 978-602-71637-1-3. p 316-320.

Firsoni. 2014. Pengaruh Pemakaian Chromolaena Odorata di Dalam Konsentrat Terhadap Produksi Gas Metana secara In-Vitro, Prosiding Seminar Nasional Sinergi Pakan dan Energi Terbarukan, SPRINT 2014. p 424-427.

Firsoni, L. Puspitasari dan L. Andini. 2011. Efek Daun Paitan (Tithonia diversifolia (HEMSLEY) A. GRAY) dan Kelor (Moringa oleifera, LAMK) Di Dalam Pakan Komplit In-Vitro, Prosiding Seminar Nasional Teknologi Peternakan dan Veteriner. ISBN 978602-8475-46-4.

Getachew, G., P. H. Robinson, E. J. DePeters and S. J. Taylor. 2004. Relationships between chemical composition, dry matter degradation and in vitro gas production of several ruminant feeds, Animal Feed Science and Technology, 111 (2004) 57-71.

Hariadi, B. T. and B. Santoso. 2010. Evaluation of tropical plants containing tannin on in vitro methanogenesis and fermentation parameters using rumen fluid, J Sci Food Agric 2010; 90: 456- 
461.

Jayanegara, A., A. Sofyan. 2008. Penentuan aktivitas biologis tanin beberapa hijauan secara in vitro menggunakan 'Hohenheim gas test' dengan polietilen glikol sebagai determinan. Media Peternakan 31: 44-52.

Krishnamoorthy, U. 2001. "RCA Training Workshop on In-vitro Techniques for Feed Evaluation". The International Atomic Energy Agency, Vienna, Austria. P 8-26.

Murni dan R. Suparjo. 2008. Buku Ajar Teknologi Pemanfaatan Limbah Untuk Pakan. Laboratorium Makanan Ternak Fakultas Peternakan Universitas Jambi.

Nista, D., H. Natalia dan S. Hindrawati. 2010. Keunggulan Turi sebagai Pakan Ternak, BPTU Sembawa, Ditjen Peternakan dan Keswan, Kementerian Pertanian. p 24-25.

Nuraini, Y. Marlida, Mirzah, R. Disafitri dan R. Febrian. 2015. Peningkatan Kualitas Limbah Buah Kopi dengan Phanerochaete chrysosporium sebagai Pakan Alternatif., Jurnal Peternakan Indonesia, ISSN 1978-3000, Juni 2015 Vol. 17 (2). 143-146 .

Pellikaana, W. F., W. H. Hendriksa, G. Uwimanaa, L. J. G. M. Bongersa, P. M.
Beckerc and J. W. Conea. 2011. A novel method to determine simultaneously methane production during in vitro gas production using fully automated equipment, Animal Feed Science and Technology 168 (2011) 196- 205.

Rahman, M. M., M. A. M. Salleh, N. Sultana, M. J. Kim and C. S. Ra. 2013. Estimation of total volatile fatty acid (VFA) from total organic carbons (TOCs) assessment through in vitro fermentation of livestock feeds.

Rosningsih, S. 2004. Pengaruh Fermentasi dengan Aspegilus niger terhadap Kandungan Nutrien dan Kecernaan Protein In-vitro Kulit Kacang Tanah sebagai Sumber Bahan Pakan Berserat. Buletin Peternakan Vol 28 (4), ISSN 0126-4400. 155-159.

Sudarwati, H. dan T. Susilawati. 2013. Pemanfaatan Sumberdaya Pakan Lokal Melalui Integrasi Ternak Sapi Potong Dengan Usahatani. J. Ternak Tropika Vol. 14, No.2: 23-30

Wanapat, M., S. Kang and S. Polyorach. 2013. Development of feeding systems and strategies of supplementation to enhance rumen fermentation and ruminant production in the tropics, Wanapat et al. Journal of Animal Science and Biotechnology, 4:32. 